\title{
Analyzing the Integration of Human Rights into Social Work Education
}

\author{
Paulette Andrea Henry \\ Department of Sociology, University of Guyana \\ 95 Amsville Housing Scheme, New Amsterdam, Berbice, Guyana \\ Tel: 592-650-7855/333-2097 E-mail: phenryugbc@yahoo.com
}

Received: May 27, 2015 Accepted: September 18, 2015 Published: November 20, 2015

doi:10.5296/iss.v3i2.8041ＵRL: http://dx.doi.org/10.5296/iss.v3i2.8041

\begin{abstract}
The understanding of human rights are important to social work education and practice especially since the global definition of social work highlights the dual role of social work as a practice based profession and academic discipline emphasizing the principles of social justice, human rights, collective responsibility and respect for diversity. Concomitantly, social work education must ensure that students know and understand human rights laws especially since human rights are inherent to all human beings and are often expressed and guaranteed by international law which Governments are expected to uphold. Social workers have a commitment as duty bearers in supporting governments in the upholding of those agreements pertinent to the wellbeing of the people. Using the University of Guyana as a frame of reference this paper examined students' knowledge on international agreements prior to leaving the University since these laws not only speak to nation states but to universal practices and many social work issues transcend borders. This paper utilized a mixed method approach to ascertain students' awareness of international human rights laws and their perceptions on the applicability to practice. The findings show that there is limited knowledge amongst social work students on human rights covenants and conventions. This assessment is instructive to social work educators locally and internationally pointing to the need for integration into the curricula. It is imperative that generalist practitioners leave the University with a clear understanding of these laws as many practice issues are transnational. There will be the need for international social work to be a taught course for undergraduates training to become generalist practitioners.
\end{abstract}

Keywords: integration, human rights laws, international social work, social work practice 


\section{Introduction}

Human rights are inherent to all human beings and are expressed and guaranteed by international law which Governments are expected to uphold. Integral to the global definition of social work which highlights the dual role of social work as a practice based profession and academic discipline are the principles of social justice, human rights collective responsibility and respect for diversity (IASSW, 2014). Concomitantly, social work education should ensure that students know and understand human rights especially since many are critical to social work practice. This was reinforced by Calma (2008) who asserts that social workers by their very definition are human rights workers. Social workers help individuals realize their rights everyday and are ideally placed to help communities claim their collective rights (Calma, 2008). Human rights teaching and learning is an imperative since social work is designed to intervene at both the micro mezzo and macro levels as practitioners work with individuals, family and community and also with policy makers. This paper is designed to underscore the importance of integrating human rights teaching and learning in social work education.

\subsection{Rationale}

A critical question for this paper is to determine how knowledge on international human rights agreements and concepts are delivered to students and if students leave the University with knowledge of key international covenants pertinent to social work practice. Understanding international human rights agreements and how they are used globally and locally are integral to local and international social work since these laws not only speak to nation states but to universal practices. However, it is unclear how education on this issue is disseminated to students and if students leave with the competencies to transfer their learning on this issue to their practice environment. Human rights literacy must be a critical aspect of social work education and students of social work at every level must understand how their role as rights advocates in every area of practice. This assessment can prove instructive to social work educators so that they directly integrate human rights conventions in their teachings especially in light of the constant demand for generalist practitioners to address local and international issues of human torture, trafficking in persons, adoptions, drug offenders, deportees, child rights violations, gender based violence amongst a range of other emerging issues.

\section{Pertinent Issues in the Literature}

\subsection{Understanding Human Rights}

The United Nations in 1948 acknowledged the recognition of the inherent dignity and the equal and inalienable rights of all members of the human family is the foundation of freedom, justice and peace in the world. A very simple but explicit definition of human rights was outlined by (Healey, 2009) which stated that at the most basic level, human rights are those rights that belong to all just because we are human. The author asserts that among the most important treaties are: the International Covenant on Civil and Political Rights (ICCPR) (1966); the International Covenant on Economic, Social and Cultural Rights (ICESCR) (1966); the 
International Convention on the Elimination of All Forms of Racial Discrimination (1969); the Convention on the Elimination of All Forms of Discrimination against Women (CEDAW) (1979); the Convention on the Rights of the Child (CRC) (1989); and the recently adopted Convention on the Rights of Persons with Disabilities (2006). However the other important human rights covenants which have gained prominence are the Minimum Age Convention (ILO Convention, 1973); Worst Forms of Child Labor Convention (ILO, 1999); (Palermo) Protocol to Prevent, Suppress and Punish Trafficking in Persons, Especially Women and Children (2000); and Convention Against Torture and Other Cruel, Inhuman or Degrading Treatment or Punishment (1984).

A very useful example in understanding the importance and relevance of human rights particularly for social work is where Witkin (1998) discussed the reconceptualization of violence against women as a human rights issue. Rather than viewing such violence as a psychological problem of women (that blames the victim) or of men (that keeps the issue individual rather than social or political), or as a relationship issue (that minimizes the violent act), feminist scholars, social workers, and activists have reframed women violence as a human rights is sue. This reframing has a number of important consequences. It creates an international context that joins women throughout the world. It brings the force of international law to bear on governments that allow or give tacit approval to such acts. It helps mobilize people to join in opposition to this situation and encourages the development of resources such as shelters for abuse victims. It communicates a message to women-victims that they are not "sick" and in need of treatment but human beings entitled to protection. This analysis is important for social workers who by the very nature of their work are called to be human rights activists. Using this as a frame of reference, all relevant international human rights laws have similar importance. Ife (2012) indicated that human rights are particularly important for social work since he strongly sees social work as a human rights profession with the international covenants providing social workers with a moral frame of reference that moves social work beyond the client system to a defined place. Moreover, Healy (2009) asserts that there is strong compatibility of the profession's mission and values with human rights suggesting a natural linkage, with human rights providing the profession with a clear direction for a social work presence at the international level, while also bridging local and national issues with global concerns.

\subsection{Human Rights as Empowerment}

Human rights teaching should therefore enable the student of social work to practice real time empowerment as they learn that rights are global realities and use human rights in their practice. Social work educators will have to undertake this mandate to ensure student preparedness. This was reinforced by Witkin (1998) who stated that the problems that social workers confront cannot be divorced from the human rights struggles within and beyond their borders. In an important sense, these problems are symptomatic of a social order that fails to identify and protect basic human rights. Gil (1994) also reiterated that the conditions that cause people to seek help from social workers and social services are invariably consequences of oppression and injustice. People therefore need to be empowered so that they understand their rights and the associated responsibilities. Students of social work will 
therefore need to be taught empowerment through a human rights lens. The empowerment process depends on what already exists in the society, but the success of the process is defined by what and how much changes on the personal level, the community level, and the social systems are connected with the process. The empowerment perspective used by practitioners employ intervention strategies intended to advance human rights, by implementing social and economic justice. Students of social work need to understand their role as potential practitioners and architects of empowerment, as they are taught key principles in preserving and restoring human dignity, and benefiting from and celebrating the diversities of humanity. Rights based education will empower students to be "empowerers" in social work practice. The social work curriculum must be framed to address empowerment through a human rights lens.

\subsection{Social Work, Human Rights and the Curriculum}

Edwards (2011) highlighted the importance of global social work, being cognizant of the fact that problems such as poverty, food security, human rights violations, HIV and AIDS and other epidemics, and the deterioration of the physical environment, are global in scope. They are "glocalised" realities, a combination of global and local, and must therefore be addressed internationally as well as locally. Thus, the magnitude of the problems highlighted by Edwards (2011) though global directly and indirectly impact social work roles and responsibilities, being key to many concerns and issues which challenge social work today. Social work must now face these global problems which often require global interventions. Thus as social work increasingly develops an international perspective, there is a need for educational approaches that more fully integrate this content into the curriculum (Hawkins and Knox, 2014), and if human rights are to be taken seriously, then they need to be an integral part of all social work education and professional development activities. The idea of the infusion approach proposed by the UN manual on Human Rights and Social Work, (1998) is to enrich the content already in the curriculum by adding specific human rights concepts and assignments. With the incorporation of human rights elements throughout social work courses, teachers and students are encouraged to examine the world and their role through a social justice lens. This is therefore consistent with social work's concern for meeting basic human needs, its respect for differences, and its social change orientation position which is at the forefront of human rights struggles hence the curriculum needs to specify these elements.

Ultimately, social workers need to do a better job of using human rights to inform practice, scholarship, and teaching. It is therefore imperative that social workers seek ways of integrating human rights within research, practice, policy, and education. Healy (1998) summarized the human rights integration argument by stating that many explanations for social work's low visibility in the global human rights movement could be advanced. These include emphasis on social and economic rights, rather than civil and political rights that command more public attention; focus on vulnerable and socially excluded groups; preference for the case approach rather than macro issues; strict observance of confidentiality impeding use of cases to serve the wider cause; a focus on needs rather than rights; and the lack of sustained global leadership on human rights by the organizations that represent the profession. Each of these suggests avenues for further efforts by the profession to mainstream 


\section{Al Macrothink}

Issues in Social Science

ISSN 2329-521X

2015, Vol. 3, No. 2

human rights in its work. It must be noted that the profession is always strengthened through in-class instruction and field based training which can only be reinforced via ongoing professional development opportunities. Schools of social work coupled with professional bodies must therefore be at the forefront of these endeavours.

Importantly, Rozas and Garran (2015) posit that a human rights perspective must be embedded in the institutions, organizations or agencies where social work students find themselves. They argue that in order to take steps towards an explicit commitment to human rights, not only will it be necessary that human rights be infused throughout the curriculum, but educators must provide opportunities for making more overt the links between human rights principles, social justice and social work. Human rights education must not be limited to the walls of the academy, but rather extend beyond to the relevant field agencies, organizations and communities. Not dissimilarly, Knox (2014) posits that as social work increasingly develops an international perspective, there is the need for educational approaches that more fully integrate this content into the curriculum. The author presents an instructional framework which shows social work educators how to develop global leadership using the theme of universal human rights. The framework emphasizes the analysis of oppressive practices of power and to pursue equality for all people through acquiring human rights literacy (knowledge), empathy (values), responsibility (action), and transforming this into global leadership (change), and provides examples of teaching strategies that assist students in developing an international perspective to guide social work practice in the globalized 21st century.

The design of the curriculum for the integration of human rights teachings is therefore extremely important. This view was expanded upon by Ife (2012) who clearly articulated that curriculum design is a very fluid and ever changing process and must respond to changes from the field, ongoing knowledge from educators and changing faculty and must be continually updated or risk irrelevance. Although acknowledging that it may not be an easy process, a critical factor underscored by the writer is that the design of curricula to address human rights teachings must consider two voices, students and clients, since these are key stakeholders who can influence how human rights is taught. Obviously if stakeholders are engaged in the process, it makes the teachings more relevant and the work of the potential practitioner easier. Further the curriculum design in itself would be an obvious form of advocacy to address human rights.

For both the student and social work educator, it is also imperative that curriculum captures the historical and ongoing contributions of social workers to human rights since this would continue to show both its importance and relevance in teachings. This was underscored by Healey (2008) who chronicled the role and interventions of social workers in international human rights. The author pointed out that almost 50 years before the Universal Declaration of Human Rights (UDHR); the founders of the social work profession were involved in the significant human rights movements of their day. The historical underpinnings of social workers are important to the curriculum as it helps students of social work understand the trend that was set by activist who fought for human rights. 
In addition, social work curriculum must not only help students understand the international covenants, but must demand that they be conversant with those signed and/or ratified by their Government. Guyana has ratified and/or acceded to several international covenants. Table 1 outlines some of those which are deemed critical to social work education and practice both locally and globally (See Table 1). Each of these agreements individually and collectively places certain demands upon nation states to see that the rights of its citizenry are upheld. Social workers by the mere calling of their vocation have a moral responsibility to know and support these covenants. However, the social work education has a major role in the preparation of students of social work so that they can transfer their learning to their varying fields of practice as they become the agents of change.

Table 1. International covenants pertinent to social work and which Guyana acceded or ratified

\begin{tabular}{|c|c|c|c|}
\hline No. & Convention & Status & $\begin{array}{c}\text { Date } \\
\text { Ratified/Signed }\end{array}$ \\
\hline & $\begin{array}{l}\text { The Convention on the Elimination of All } \\
\text { Forms of Discrimination against Women } \\
\text { (CEDAW) (1979); }\end{array}$ & Ratified & 17-Jul-80 \\
\hline 2. & Optional Protocol to CEDAW (1999) & Ratified & 17-Jul-80 \\
\hline 3. & $\begin{array}{l}\text { The Convention on the Rights of the Child } \\
\text { (CRC) (1989) }\end{array}$ & Ratified & 14-Jan-91 \\
\hline 4. & $\begin{array}{l}\text { Optional CRC Protocol on Sale of } \\
\text { Children, Child Prostitution and Child } \\
\text { Pornography }\end{array}$ & Ratified & 30-Jul-10 \\
\hline 5. & $\begin{array}{l}\text { Optional CRC Protocol on Involvement of } \\
\text { Children in Armed Conflict }\end{array}$ & Ratified & 11-Aug-10 \\
\hline 6. & $\begin{array}{l}\text { Convention on the Rights of Persons with } \\
\text { Disabilities (2007) }\end{array}$ & Signed & 11-Apr-07 \\
\hline 7. & $\begin{array}{l}\text { Minimum Age Convention (ILO Convention } \\
\# 138,1973 \text { ) }\end{array}$ & Ratified & 15-Apr-95 \\
\hline & $\begin{array}{l}\text { Worst Forms of Child Labor Convention } \\
\text { (ILO \#182, 1999) }\end{array}$ & Ratified & 15-Jan-01 \\
\hline & $\begin{array}{l}\text { Protocol to Prevent, Suppress and Punish } \\
\text { Trafficking in Persons, Especially Women } \\
\text { and Children }\end{array}$ & Acceded & 14-Sep-04 \\
\hline & $\begin{array}{l}\text { Rome Statute of the International Criminal } \\
\text { Court }\end{array}$ & Ratified & 24-Sep-04 \\
\hline & $\begin{array}{l}\text { International Covenant on Civil and } \\
\text { Political Rights (1966) }\end{array}$ & Ratified & 15-Feb-77 \\
\hline & $\begin{array}{l}\text { International Covenant on Economic, Social } \\
\text { and Cultural Rights (1966) }\end{array}$ & Ratified & 15-Feb-77 \\
\hline 13. & $\begin{array}{l}\text { Convention Against Torture and Other } \\
\text { Cruel, Inhuman or Degrading Treatment or } \\
\text { Punishment (1984) }\end{array}$ & Ratified & 19-May-88 \\
\hline
\end{tabular}

Source: Extracted from UNICEF Guyana, CPMA Report, 2014/Guyana Report on Aging, 2012 


\section{Macrothink}

\section{Methodology}

Using the University of Guyana as a frame of reference, this paper utilized both qualitative and quantitative approaches to review the curricula of the social work program and conduct a survey of final year social work students in both Diploma and Degree programs to ascertain how international human rights laws are delivered to students of social work and their level of awareness of the laws and its applicability to their work as practitioners.

Content analysis was conducted of the social work courses offered at the Diploma and Degree Level. These courses were reviewed to see where direct reference was made to human rights covenants in the curricula. Further a survey was conducted with final year Diploma and Degree students of Social Work to find out from them where human rights covenants and precepts were used in the delivery of course content. The data was analyzed using the statistical package for social science (SPSS).

\subsection{Reliability of Instrument}

The instrument was tested to ensure that it was free from random error using Cronbach alpha coefficient of reliability. A coefficient of 0.943 was obtained. This is an indication that the questionnaire had good internal consistency and was reliable for gathering data. Cohen and Manion (2000) have stated that an instrument that yields o coefficient of 0.70 and higher is considered reliable.

\subsection{Sample}

The research targeted final year Diploma and Degree students since in Guyana one can join the social work profession after completing the two year Diploma program. Purposive sampling was done since the researcher wanted to target final year students of both the Degree and Diploma program. This approach was purposive primarily because the numbers were small. A total of fifty (50) participants, that is, twenty three (23) final year Diploma and twenty seven (27) final year Degree students are enrolled in the University of Guyana, Tain Campus.

\subsection{Data Collection}

Participants were drawn from the Final year social work classes, both Diploma and Degree programs. Permission was sought from faculty to utilize some of their teaching time to have students complete the questionnaires. Students completed the questionnaire in approximately twenty minutes. The participants were told about the purpose of the purpose of the questionnaire, but were not compelled to complete same. They were also told of the study procedure and about how confidentiality and anonymity will be managed. The questionnaire contained both structured and unstructured questions so that the researcher was able to extract views and other pertinent details from the study participants.

\subsection{Limitations}

Future research needs to consider faculty perceptions on integrating human rights teachings into the curriculum as well as their perceptions of international social work and the correlations. Students' can only attest to what they know and their knowledge is primarily driven by their learning environment which is stimulated by their lecturers. 


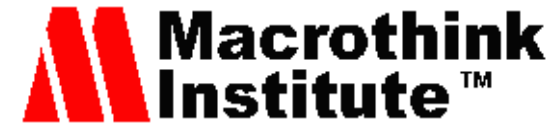

\section{Findings}

\subsection{Demographic Data}

The research was conducted with both final year Diploma and Degree program. In both groups there was a high response rate to the survey instrument. A total of 40 of the 50 students enrolled in both programs participated in the survey. Significantly of those who completed the survey, 87 percent (20 of 23) were participants of the final year Diploma class and 74.1 percent (20 of 27) from the Degree class. The gender disparity of this study reflects the gender disparity across all the social work classes where males are the minority. The number of male students polled was 7 or 17.5 per cent. $57.1 \%$ or four (4) of these males were from the Degree class whilst the remaining three (3) were Diploma students. Thirty three or 82.5 percent of the participants were female.

\subsection{Employment}

The research sought to find out where the respondents worked (See Table 1). The data showed that 20 percent of the respondents worked in primary social work agencies whilst 17.5 percent worked in secondary agencies and 25 percent were employed either as teachers or in other "non social work" agencies. Fifteen or 37.5 percent of the participants were not "formally" employed.

Table 2. Employment of study participants

\begin{tabular}{llccc}
\hline No. & Social Work Agencies & $\begin{array}{c}\text { No. of } \\
\text { Respondents }\end{array}$ & Percentage & $\begin{array}{c}\text { Cumulative } \\
\text { Percent }\end{array}$ \\
\hline 1. & Child Protection & 4 & 10.0 & 10.0 \\
2. & Probation and Social & 2 & 5.0 & 15.0 \\
& Services & 2 & 5.0 & 20.0 \\
3. & School social Work & 1 & 2.5 & 22.5 \\
4. & Legal Affairs & 6 & 15.0 & 37.5 \\
5. & NGO & 10 & 25.0 & 62.5 \\
6. & Other & 15 & 37.5 & 100.0 \\
7. & Not employed & $\mathbf{4 0}$ & $\mathbf{1 0 0 . 0}$ & \\
\hline
\end{tabular}

\subsection{Knowledge of Human Rights Laws}

The key question that this study sought to answer was whether students of social work who were leaving the University either at the Diploma or Degree level had knowledge of social work related laws and if their knowledge were acquired from their in-class instructional (teaching and learning) activities. Interestingly, the data show that just over half of the respondents, 22 or 55 per cent of the students had knowled ge of human rights covenants (See Figure 1) and could have identified these laws (See Table 2). However a significant number 


\section{Macrothink}

Issues in Social Science

ISSN 2329-521X

2015, Vol. 3, No. 2

of the students indicated that they had no knowledge, 18 or 45 percent. It is important to note however that those students who knew of the laws had a limited knowledge of all of the international laws, even those which Guyana had either acceded to or ratified. This response strongly suggests that human rights teachings are not inherent in social work curricula, hence student knowledge is limited.

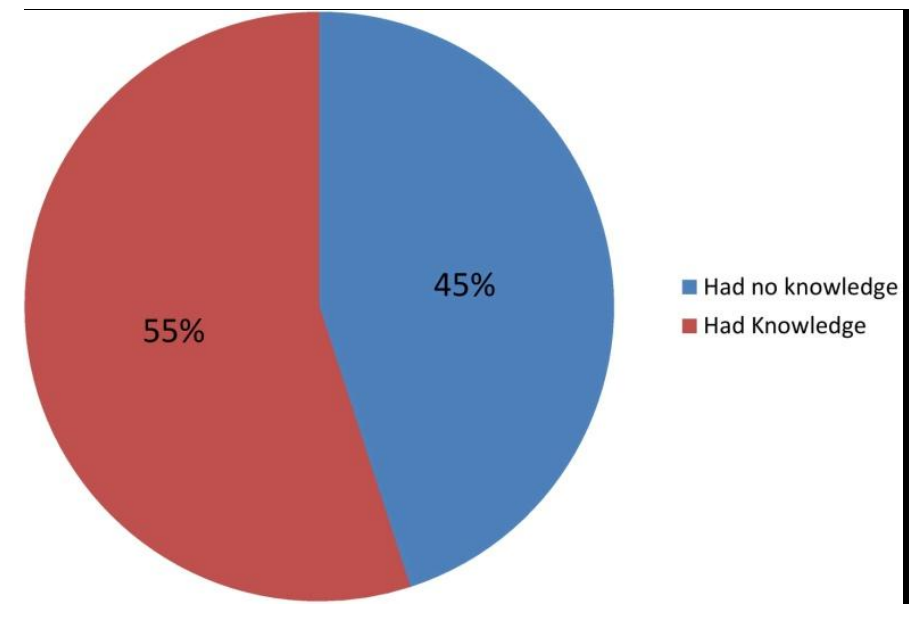

Figure 1. Students' knowledge of Human Rights Laws

Students knowledge were limited to only four of the thirteen key pieces of international legislation that were of critical importance to social workers. Those which the students identified were the UN Convention on the Elimination of Discrimination against Women (20 percent, the Convention on the Rights of the Child (20 percent) the International Covenant on Economic, Social and Cultural Rights (12.5 percent), and the Madrid International Plan of Action on ageing (12.5 percent).

Table 3. Human rights agreements known to students

\begin{tabular}{lccc}
\hline Human Right Law & No. of Respondents & Percent & Cumulative Percent \\
\hline CEDAW & 8 & 20 & 20.0 \\
CRC & 8 & 20 & 40.5 \\
ESCRC & 5 & 12.5 & 52.5 \\
MIPAA & 1 & 2.5 & 55.0 \\
No Response & 18 & 45.0 & 100.0 \\
Total & $\mathbf{4 0}$ & $\mathbf{1 0 0 . 0}$ & \\
\hline
\end{tabular}

When analyzed by cohort, the data also showed that final year Diploma students had limited knowledge of Human Rights covenants. Only 26.1 percent of the Diploma students (6 of 23) had knowledge of the covenants whilst the large majority of students with knowledge of the covenants were final year Degree students, 16 of 27 or 59.3 percent. Of note too is that students at the Diploma level indicated that they garnered their knowledge on human rights 


\section{Macrothink}

Issues in Social Science ISSN 2329-521X 2015, Vol. 3, No. 2

from one course, Social Policy and Social Administration whereas at the Degree level students indicated that they received their information from five courses- Social Work and the Aging, Professional Development, Women and Gender Studies as well as Corrections and Punishment (See Table 3). Since final year Degree students would have had greater exposure to both classroom and field practice experiences, it had been anticipated that the percentage of students with knowledge at this level would have been higher. Interestingly, the findings also show that one faculty member taught four (4) of the Courses at different periods.

With more than twenty (20) courses being taught and only three members of faculty addressing human rights in their teachings suggest that this is subjective and may also imply that faculty needs to be equipped to deliver this information within their curriculum or that faculty may be restricting their teachings to the curriculum. This therefore suggests that human rights, particularly those relevant to the course offering need to be directly infused within the curriculum so that it becomes a mandatory part of the course curriculum and teachings.

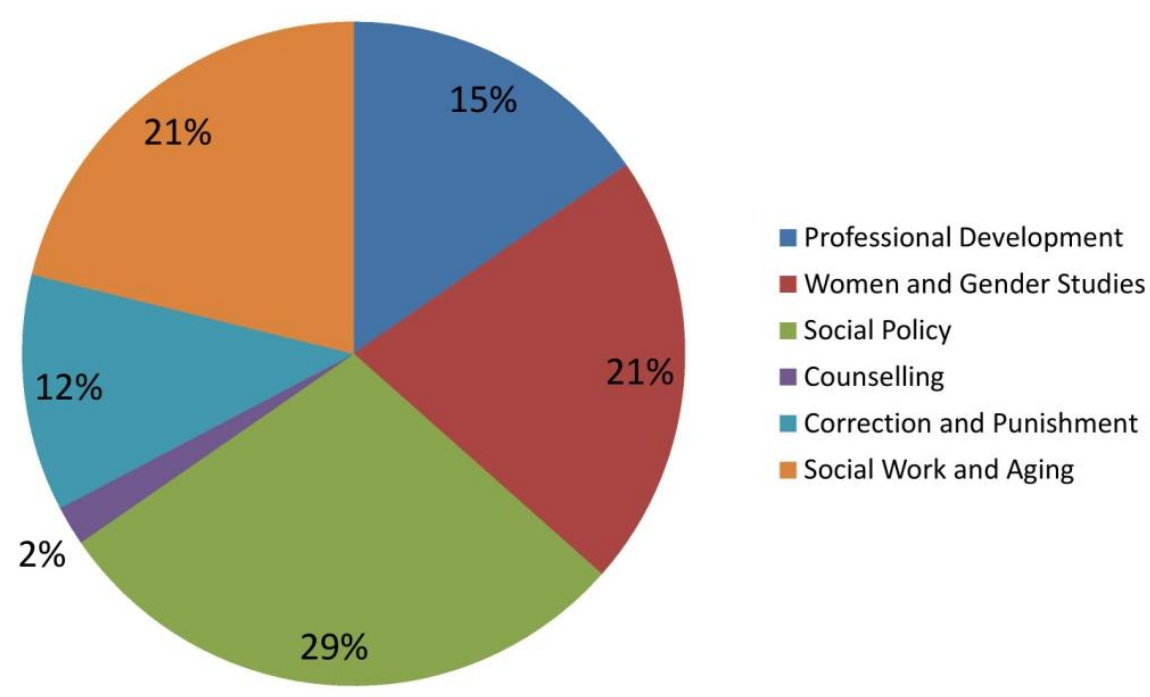

Figure 2. Courses where students were taught human rights laws

The researcher reviewed the Courses offered at both the Diploma and Degree level to assess areas where human rights education can be taught. There are ten courses at each level where human rights teachings can be integrated into the program offering (See Table 4). 


\section{Macrothink}

Issues in Social Science

ISSN 2329-521X

2015, Vol. 3, No. 2

Table 4. Diploma and degree courses offered at the University of Guyana with potential for human rights education

\begin{tabular}{ll}
\hline Course Title & Course Name \\
\hline DSW 1102 & Introduction to Social Work 1 \\
DSW 1203 & Introduction to Social Work 11 \\
SOC 1100 & The Study of Society \\
SOC 1200 & Introduction to Sociological Theory \\
POL 1200 & Introduction to Political System and Institutions \\
DSW 2101 & The Theory and Practice of Social Work 1 \\
DSW 2104 & Crime and Criminology \\
DSW 2202 & Contemporary Social Problem Analysis \\
DSW 2105 & Social Policy and Legislation \\
DSW 2205 & Social Administration \\
& \multicolumn{1}{c}{ Degree Courses } \\
DSW 3107 & The Sociology of Punishment \& Corrections \\
DSW 3202 & Social Service Delivery Analysis \\
DSW 3204 & Program Evaluation \\
DSW 3208 & Social work in Addictions \\
DSW 3205 & Social Work and the Aging \\
SOC 3209: & Poverty Analysis \\
WST 4100 & Gender and Development \\
DSW 3104: & Community Practice \\
DSW 3100 & Professional Development 1 \\
DSW 3200: & Professional Development 11 -Practicum \\
\hline
\end{tabular}

It must be also stated that whilst a majority of the students in the survey (55 percent) had indicated that they learnt about Human Rights agreements from their class room teachings, the other sources of learning cited were the media, additional readings and their place of work. With almost 40 percent of the students already working in a primary or secondary setting, it is imperative that teachings for generalist practitioners be cognizant of the role of social work educators to equip students to be able to transfer their learning to the work setting.

\subsection{The Importance of Human Rights Covenants to Social Work Education and Practice}

Why is it important for a social work student to understand human rights agreements? This was one of the pivotal questions in the study and notably, the primary reason cited by almost half of the participants (43.4 per cent) alluded to international social work since they indicated that there are client issues which needed international efforts. 
Table 5. Students perceptions on the importance of human rights covenants

\begin{tabular}{|c|c|c|c|c|c|}
\hline & & Frequency & Percent & $\begin{array}{c}\text { Valid } \\
\text { Percent }\end{array}$ & $\begin{array}{c}\text { Cumulative } \\
\text { Percent }\end{array}$ \\
\hline \multirow{3}{*}{ Valid } & $\begin{array}{l}\text { Client Issues on } \\
\text { Local/Global Scale }\end{array}$ & 23 & 43.4 & 59.0 & 59.0 \\
\hline & No Response & 16 & 30.2 & 41.0 & 100.0 \\
\hline & Total & 39 & 73.6 & 100.0 & \\
\hline Missing & System & 14 & 26.4 & & \\
\hline Total & & 53 & 100.0 & & \\
\hline
\end{tabular}

\subsection{Students Understanding of International Social Work}

Understanding human rights and its concomitant covenants, move social work teachings and practice beyond into the international realm of the profession. Practice therefore has to embrace an understanding of international social work. It was therefore important to this study to ascertain from students their perception of international social work. When students questioned provided multiple responses (See Table 4). The general perceptions garnered from the findings suggest that international social work was beyond the nation state or the boundaries of a country. These findings support the definition of international social work proposed by Akimoto (2011) stating that international is social work which deals with problems caused between nations or across national boundaries or efforts beyond national boundaries to solve those problems. International social work thinks of and acts for the well-being of all people on this earth, or 6.5 billion people in some 200 countries and districts. International social work does not attach any special meaning or importance in value to any specific country or people. This is directly linked to the responses provided on the importance and relevance of students' understanding human rights agreements, since the primary reason cited by cited by a significant group ( 43.4 per cent) alluded to international social work since they indicated that there are client issues which needed international efforts.

Table 6. Students' understanding of international social work

\begin{tabular}{|c|c|c|c|c|c|}
\hline \multicolumn{2}{|c|}{ Responses } & \multicolumn{3}{|c|}{ Frequency Percent Valid Percent } & $\begin{array}{c}\text { Cumulative } \\
\text { Percent }\end{array}$ \\
\hline \multirow{5}{*}{ Valid } & $\begin{array}{l}\text { Having the Ability to work } \\
\text { universally and acquire } \\
\text { Knowledge }\end{array}$ & 2 & 3.8 & 5.1 & 5.1 \\
\hline & $\begin{array}{lll}\text { Global } & \text { Perspective } \\
\text { Helping } & \end{array}$ & 5 & 9.4 & 12.8 & 17.9 \\
\hline & $\begin{array}{l}\text { Social Work on a Global } \\
\text { Scale }\end{array}$ & 15 & 28.3 & 38.5 & 56.4 \\
\hline & $\begin{array}{l}\text { Understanding } \\
\text { Local/Global Issues }\end{array}$ & 9 & 17.0 & 23.1 & 79.5 \\
\hline & $\begin{array}{l}\text { No Response } \\
\text { Total }\end{array}$ & $\begin{array}{c}8 \\
39\end{array}$ & $\begin{array}{l}15.1 \\
73.6\end{array}$ & $\begin{array}{c}20.5 \\
\mathbf{1 0 0 . 0}\end{array}$ & 100.0 \\
\hline
\end{tabular}




\section{Conclusions}

Social work curriculum must be explicitly designed to infuse human rights covenants into the curriculum. It should not be left to serendipitous learning. This should be mainstreamed at all levels within the curricula since the data clearly show that there is limited knowledge amongst social work students who exit the University with only a Diploma. These findings clearly suggest a deficit in the Diploma program pertinent to human rights education. Students leaving any tertiary institution and entering practice must be equipped with the enough knowledge and skills to understand and use their human rights lens for practice. A policy that mandates purposeful integration into the curricula is therefore imperative so that generalist practitioners leave the University with a clear understanding of human rights as many practice issues are transnational. As articulated earlier, teachings can no longer be serendipitous or subjective based on the interests of a few faculty members it must be purposive.

With social work becoming an international discipline, there is the need for potential practitioners as well as educators to be empowered so that they become conversant with human rights covenants which informs both teachings and practice. The limited knowledge on human rights legislation strongly suggest that social work educators may themselves be needing professional development sessions on these covenants so that they become competent and be better able to impart the relevant teachings to potential practitioners. Students can only transfer what was taught and understood. It is within this context that teaching for international social work must become a front burner issue with human rights being an important and necessary aspect of teaching and practice for international social work. Educators have to be proactive and premeditated in their curriculum design and thereby move away from reactive approaches to teaching. There is no other way as social work interventions rapidly become borderless.

\section{References}

Agius, A. (Ed). (2010). Standards in Social Work Practice meeting Human Rights. IFSW Europe. International Federation of Social Workers European Region.

Akimoto, T. (2011). What Is International Social Work? Its contribution to social work in a global society. [Online] Available: http://www.ash-berlin.eu/100-Jahre-ASH/symposium /doc/3_5_akimoto.pdf

Calma, T. (2008). The role of social workers as human rights workers with Indigenous people and communities. Proceedings of the Social Work Orientation Week Seminar Australian Catholic University. [Online] Available: https://www.humanrights.gov.au/news/speeches /role-social-workers-human-rights-workers- indigenous-people-and-communities.

Edwards, B. (2011). Social Work Education and Global Issues: Implications for Social Work Practice. Arkansas State University Education, 131(3), 580-586.

Hawkins, C. A. (2014). Educating for international social work: Human rights leadership. International Social Work, 5(3), 248-257. http://dx.doi.org/10.1177/0020872813519462 


\section{Macrothink}

Issues in Social Science ISSN 2329-521X 2015, Vol. 3, No. 2

Hawkins, C. A., \& Knox, K. (2014). Educating for international social work: Human rights leadership. International Social Work, 57(3), 248-257. http://dx.doi.org/10.1177 /0020872813519462

Hawkins, C., \& Knox, K. (2014). Education for International Social Work. Human Rights. International Social Work, 57(3), 248-257. http//dx.doi.org/10.1177/0020872813519462

Healey, L. (2008). Exploring the history of social work as a human rights profession. International Social Work, 51(6), 735-748. http://dx.doi.org/10.1177/0020872808095247

Healy, L. M. (2008). Exploring the history of social work as a human rights. International Social Work, 51(6), 735-748. http//dx.doi.org/10.1177/0020872808095247

Ife, J. (2012). Human Rights and Social Work towards Rights-Based Practice (3rd ed.). Cambridge University Press.

Reamer, F. G. (1994). The foundations of social work knowledge. Colombia University Press, New York.

Reichert, E. (2003). Social Work and Human Rights: A Foundation for Policy and Practice (p. 295). Columbia University Press, New York.

Rozas, L. W., \& Garran, A. (2015). Towards a Human Rights Culture in Social Work Education. Br J Soc Work. http://dx.doi.org/10.1093/bjsw/bcv032

Witkin, S. (1998). Human Rights and Social Work. Oxford University Press, 43(3), 197-201. [Online] Available: http://www:jstor.org/stable/23718189 